\title{
Study of Earthquake Activities in the Lokop-Kutacane Fault in Aceh Province, Indonesia
}

\author{
Abdi Jihad* and Vrieslend Haris Banyunegoro \\ Badan Meteorologi, Klimatologi dan Geofisika, Stasiun Geofisika Mata Ie Banda Aceh \\ Jl. Raya Mata Ie, Banda Aceh 23352
}

\begin{abstract}
Aceh's tectonic conditions are always interesting to study. There are at least 5 fault segments out of 19 active fault segments in the Sumatra fault system which are the source of earthquakes in Aceh. Most recent, a study of the activity of the series of earthquakes that occurred in Gayo Lues indicates the reactivation of the Lokop-Kutacane fault. In September 2020, there was a high number of earthquakes occurring in the LokopKutacane fault. The fault length analysis shows a maximum magnitude of 7.6, however, the Lokop-Kutacane fault, historically showed significant activity in 1990 with earthquakes having a maximum magnitude of M 6.8. In accordance with the calculation of rock parameters (b-value) of $0.78, \mathrm{CDF}$ and PDF analyses also show that the highest probability of earthquake activity on earth earthquakes with a magnitude of $3 \leq \mathrm{M} \leq 4$ is $28.9 \%$. This suitability means that both analysis results show that the rock characteristics of the Lokop-Kutacane fault are classified as fragile, or unable to withstand stress for a long time. In other words, the accumulated energy tends to be dislodged more quickly to become an earthquake with medium magnitude $(3 \leq \mathrm{M} \leq 4)$ The analysis of the focal mechanism shows two nodal planes with strike directions of 62 and 153 while the earthquake distribution tends to be northwest-southeast. The calculation of rock parameters gives a-b -value of 0.78 which corresponds to the characteristics of the Lokop-Kutacane fault.
\end{abstract}

Keywords: b-value; Lokop-Kutacane fault; Probability Density Function.

*Corresponding author: abdijihad.bmkg@ gmail.com

Article history: Received 10 October 2020, Accepted 03 December 2020, Published January 2021.

http://dx.doi.org/10.12962/j24604682.v17i1.6988

2460-4682 (CDepartemen Fisika, FSAD-ITS

\section{INTRODUCTION}

Aceh Province is well known as an active seismic region that produces many earthquakes. The magnitudes of the earthquakes vary from small earthquakes $(\mathrm{M}<1)$ to large events $(M>8)$. The 2004 Aceh earthquake $(M=9.0)$, seemed as the breakthrough for many seismic sources to produce more earthquakes. The increase in earthquake sources activities is indicated by more earthquakes occurred that have magnitude more than $\mathrm{M}=6$. The common sources of earthquakes are faults and subduction zone. Fault-sourced earthquake tends to be smaller in magnitude than the subduction zone earthquake. However, with the same magnitude $(M=6)$, the earthquake caused by fault can be more dangerous as it occurred near densely populated area. The 2013 and 2016 earthquakes were good examples of how fault-sourced earthquake located near densely populated area could devastate the cities of Bener Meriah and Pidie Jaya [1, 2].

The subduction zone is formed by the convergency between Indo-Australia and Eurasia plates. While the Sumatra Fault System is a series of fault segments that stretch from Weh Island to Semangko Bay. The Sumatra Fault System is segmented into 19 faults and some of them are located in Aceh Province. Several faults are well identified, namely Aceh fault, Seulimeum fault, Batee fault, Tripa fault, and Lhokseumawe fault (Fig.1) [3-5]. Those segments are identified morphologically and also by earthquake events. Nevertheless, the earthquake catalog of Badan Meteorologi Klimatologi dan Geofisika (BMKG) shows that there are earthquakes that are located nowhere near identified fault segments. This indicates that there are sources of earthquakes that are yet identified but potentially produce earthquakes. For example, Panteraja, Lampahan and Nisam fault were identified by earthquakes events $[2,6]$. Furthermore, there are segments which are identified morphologically but have no events recorded so that categorized as inactive fault like Lokop-Kutacane fault [7].

In September 2020, there was an increase in earthquake activity associated with Lokop-Kutacane fault in Gayo Lues, Southeast of Aceh Province. This research is conducted to analyze the characteristic of earthquake series located at LokopKutacane fault using least square linear regression. The historically largest earthquake probability is also calculated using Probability Density Function (PDF) and Cumulative Distribution Function (CDF) as the basis of disaster risk reduction effort.

\section{METHODS}

\section{Magnitude-Fault Length Correlation}

Magnitude is the representation of the amount of energy released when an earthquake occurs. Earthquake energy corresponds to rupture area that consists of length and width of 


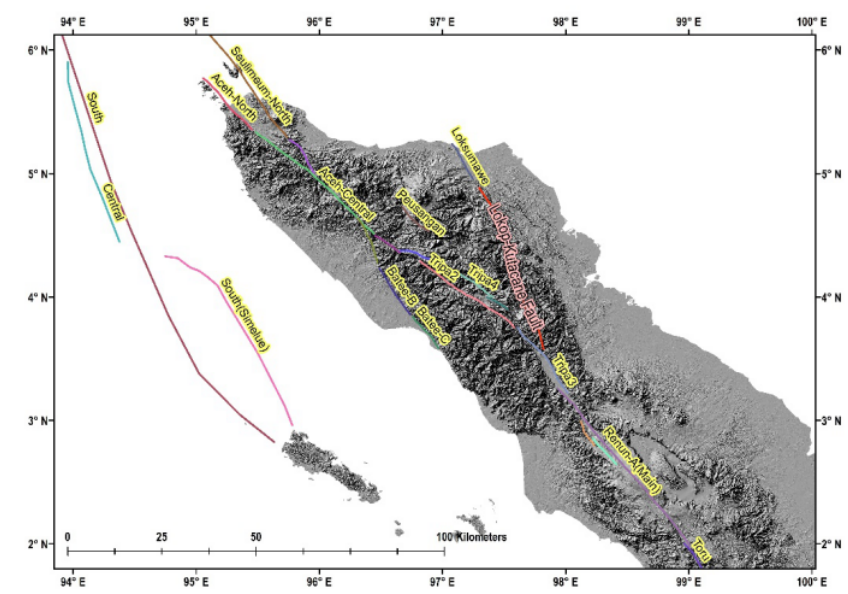

FIG. 1: Sumatra Fault System in Aceh Province [3, 5].

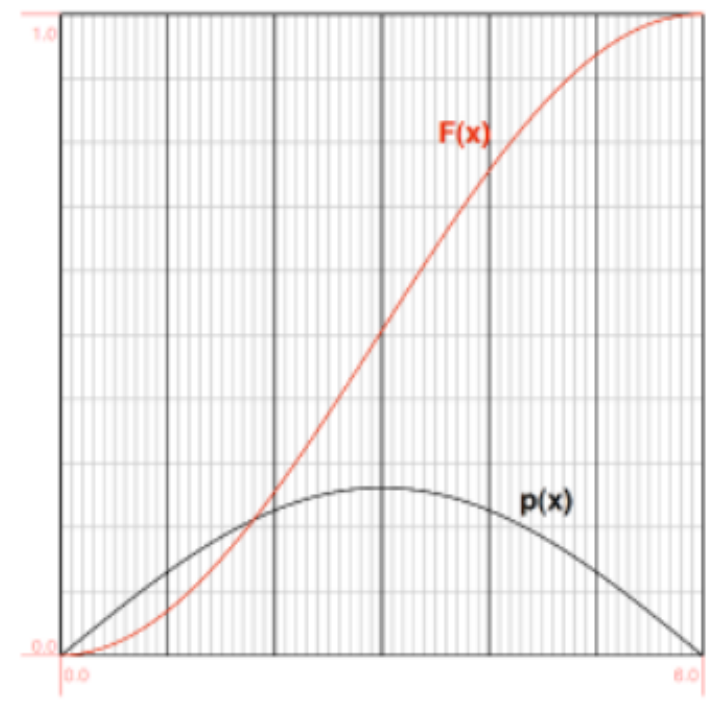

FIG. 2: Illustration of Probability Density Function and Cumulative Distribution Function.

fault. Some researchers had given equations to convert earthquake magnitude into fault length. Some of them are given by Wells dan Coppersmith (1994) dan Papazachos (2004) [8,9]. Wells dan Coppersmith (1994) gave the equation that is used in this research to calculate fault length and expressed as:

$$
\log (R L D)=a+b * M
$$

where RLD is fault length, $a$ and $b$ are constants, and $M$ is magnitude.

\section{Frequency-Magnitude Relationship}

Richter provided a relationship between earthquake frequency and magnitude which is known as Gutenberg-Richter Law which expressed as:

$$
\log N=a-b M
$$

where $\mathrm{N}$ is earthquake events with magnitude $\mathrm{M}$, $\mathrm{a}$ and $\mathrm{b}$ is seismic parameter, and $\mathrm{M}$ is magnitude. Seismic parameter, b-value, is calculated using two commonly used method, namely least square linear regression and maximum likelihood estimation. The least square linear regression is a decent approach to find relationship in a set of data, which in this case is earthquake data, it is associated with a particular earthquake source. In the other hand, maximum likelihood estimation is preferable to calculate b-value spatially. Since this research needs to calculate b-value in Lokop-Kutacane fault, the least square linear regression is applied to earthquake series data.

\section{Probability Density Function (PDF) and Cumulative Distribution Function (CDF)}

Earthquake recurs in a certain time span. However, an uncertainty is always present in every repeatable process. A common approach to calculate the possibility of an earthquake to recur is using a combination of Probability Density Function (PDF) and Cumulative Distribution Function (CDF). PDF is used to give what is the probability of something (in this term is earthquake with a given magnitude) to occur based on the data collected. While CDF gives a cumulative probability of earthquake with a given magnitude to occur. PDF has a value of 1 in total, while CDF will increase from almost zero to reaching 1 in the end of magnitude of earthquake as illustrated in Fig.2.

Cumulative Distribution Function is expressed as:

$$
F_{M}(m)=P\left(M \leq m \mid M \geq m_{\text {min }}\right)
$$

and Probability Density Function is a derivative of CDF that is written as:

$$
f_{M}(m)=\frac{d}{d m} F_{M}(m)
$$

\section{Research steps}

The research is initiated by collecting earthquake catalog associated with Lokop-Kutacane Fault. The earthquake catalog includes location (latitude and longitude), depth $(\mathrm{km})$ and magnitude (M) of the earthquakes. The earthquake catalog is obtained from Stasiun Geofisika Aceh Besar of Badan Meteorologi, Klimatologi, dan Geofisika (BMKG). The analysis is done by building a graph then establish a relationship between number of earthquakes (N) and magnitude (M) using least square linear regression. Linear regression established by analyzing two parameters which are cummulative (number of earthquakes $\geq \mathrm{M}$ ) and non cummulative (number of earthquakes at certain magnitude range). The highest number of non cummulative parameter is determined as Magnitude of Completeness $(\mathrm{Mc})$. The cummulative parameter with magnitude above magnitude of completeness will be used to calculate linear regression to obtain b-value. The flowchart of this research is shown in Fig.3.

\section{RESULTS AND DISCUSSION}

Based on the catalog, seismic activity in Lokop-Kutacane fault is relatively low compared to the other fault in Aceh 


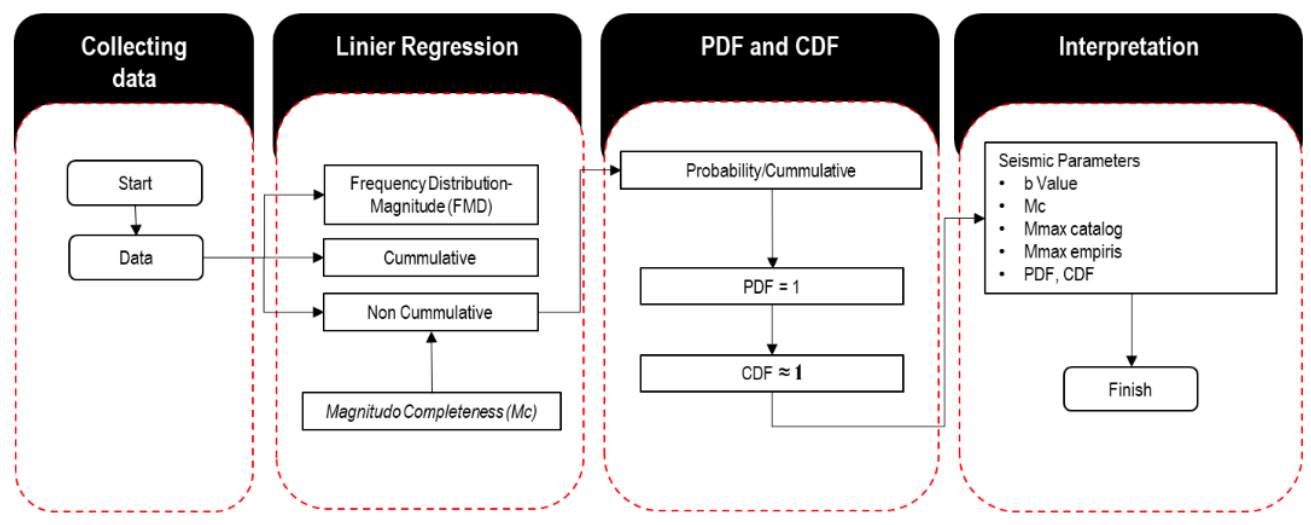

FIG. 3: Flowchart of the research.

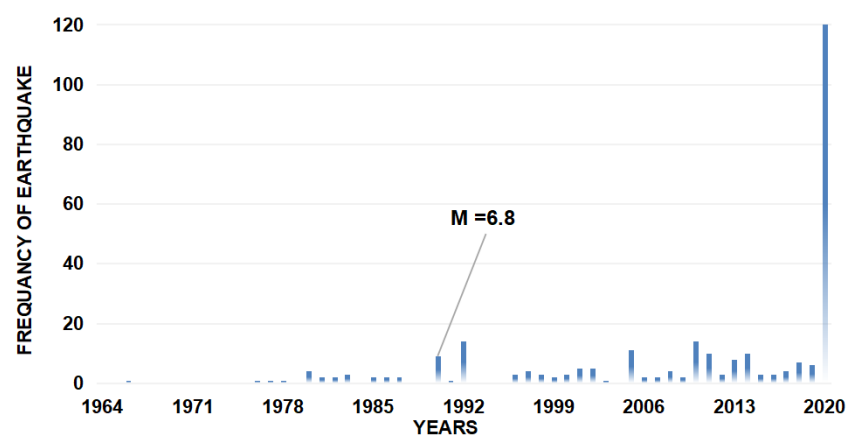

FIG. 4: Graph of earthquake activity in the Lokop-Kutacane Fault Segment, period of 1964 to 2020 (Source: Stasiun Geofisika Aceh Besar, BMKG).

Province. Since 1964 to 2020, Lokop-Kutacane fault has produced 184 earthquakes and the largest one is the 1990 earthquake with magnitude $\mathrm{M}=6.8$ (Fig. 4). Lokop-Kutacane fault is a northwest-southeast fault with a length of $\sim 160$ $\mathrm{km}$. The fault length analysis of Lokop-Kutacane fault using Wells-Coppersmith relationship shows that Lokop-Kutacane fault can produce an earthquake up to $\mathrm{M} 7.6\left(\mathrm{M}_{\max }=7.6\right)$.

The PDF and CDF analysis indicate that the highest earthquake potential of Lokop-Kutacane fault is in the range of $\mathrm{M}$ $\leq 3$ to $\mathrm{M} \leq 4$ which is $38 \%$. While the probability of historically largest earthquake, $\mathrm{M} \geq 6.8$, is about $0.098 \%$.

The series of Gayo Lues earthquakes were initiated at September $27^{t h}$ 2020. Since that date to September $30^{t h}$ 2020, there were 120 earthquake events as shown in Fig.6. The second day is the most active at this series with 49 earthquakes recorded.

The distribution of earthquakes series in Gayo Lues at September 2020 is located around Lokop-Kutacane fault as shown in Fig.7. The magnitudes of the earthquakes vary from $\mathrm{M}=2.8$ up to $\mathrm{M}=4.4$. The focal mechanism is a good method to understand mechanism of earthquake. The focal mechanism also can be used to give strike of the earthquake. The focal mechanism analysis of Lokop-Kutacane fault shows that the earthquakes in this area has dextral type of mechanism.

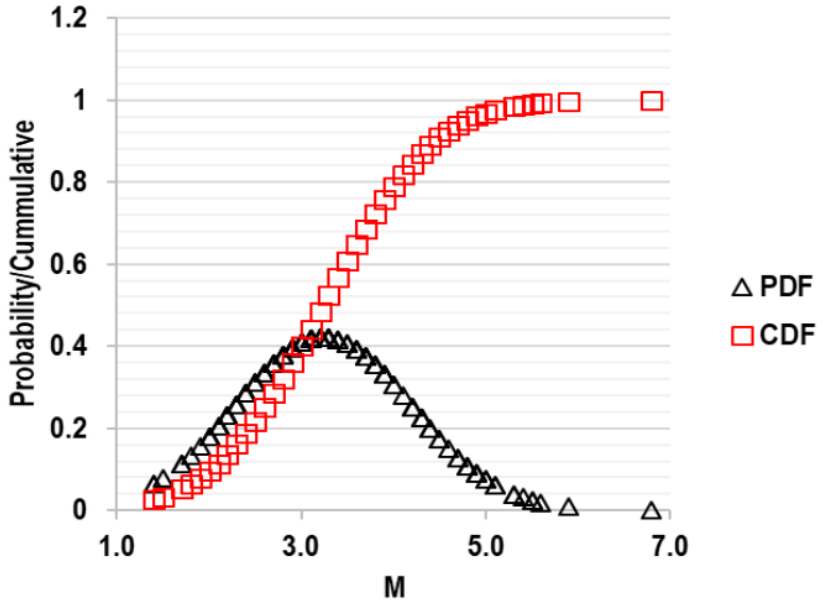

FIG. 5: Probability Density Function (PDF) and Cumulative Distribution Function (CDF) Graph of earthquakes in the Lokop-Kutacane Fault Segment (Source: Data Processing, 2020).

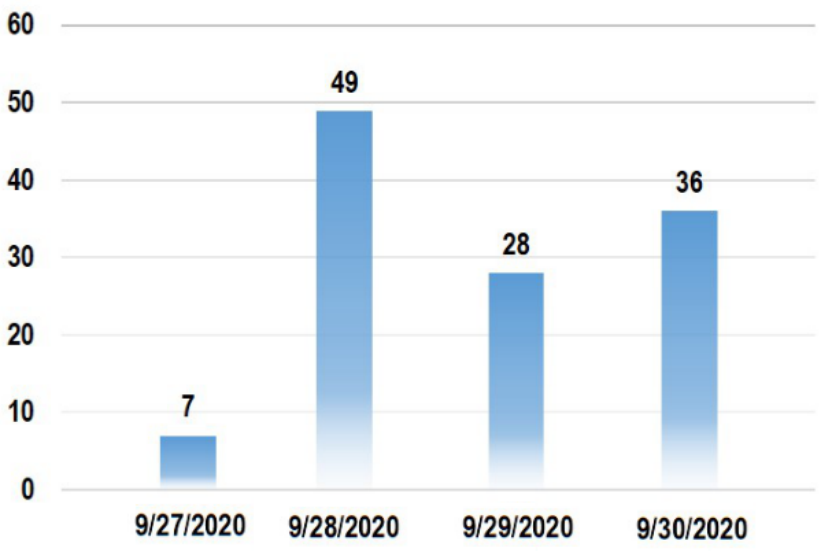

FIG. 6: Graph of Frequency of Earthquake per days (Source: Stasiun Geofisika Aceh Besar, BMKG). 


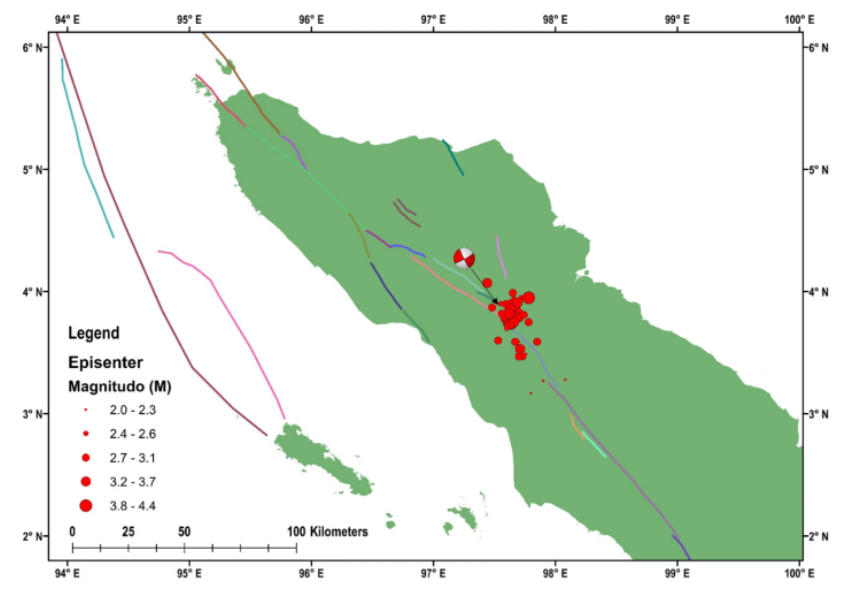

FIG. 7: Seismicity of Gayo Lues (Source: Stasiun Geofisika Aceh Besar, BMKG).

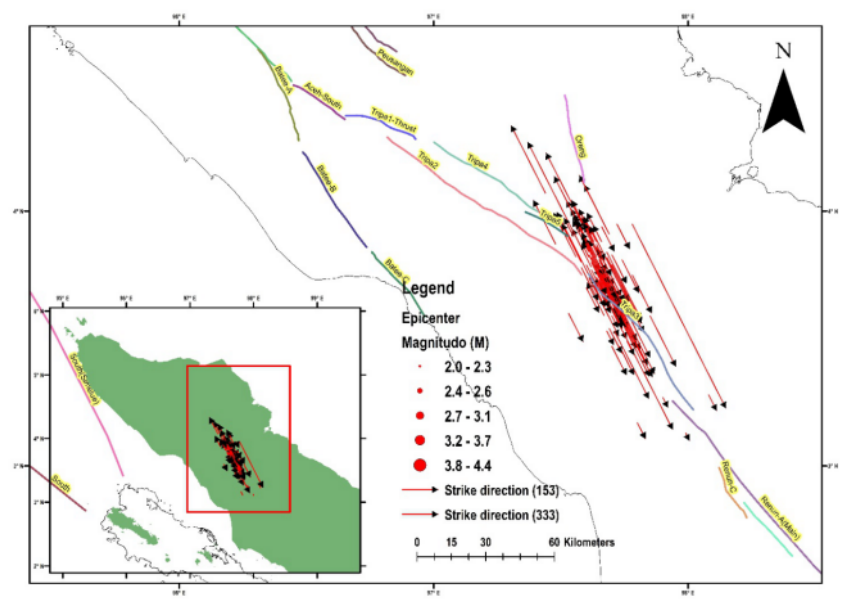

FIG. 8: Direction of Strike of Gayo Luess Earthquake (Source: Stasiun Geofisika Aceh Besar, BMKG).

The analysis also shows that the nodal plane 1 has strike of 62 degrees and the second nodal plane has strike of 153.

Fig.8 illustrates the pattern of earthquake series of LokopKutacane fault based of the first occurred earthquake at September $27^{t h}$ 2020. The pattern of earthquake series fits the nodal plane 2 of focal mechanism analysis earlier. The pattern is mostly directed into southeast and northwest. This pattern also fits with the direction of Lokop-Kutacane fault. Another fact is geologically, the earthquake series happened around Mount Kembar as shown in Fig.9. This fact indicates that there is possibility that the earthquake series is an earthquake swarm. The earthquake swarm is a series of earthquake that is caused by the energy released by ductile rocks in a certain time span which is usually located near volcanic area.

Fig.10 shows b-value calculated using least square linear regression. The value of $\mathrm{b}$ parameter is 0.7832 with a Magnitude of Completeness $(\mathrm{Mc})=2.9$. The b-value tells us that the area of research has ductile rocks characteristic [10], [11] - An area with ductile rocks generally has low resistance to

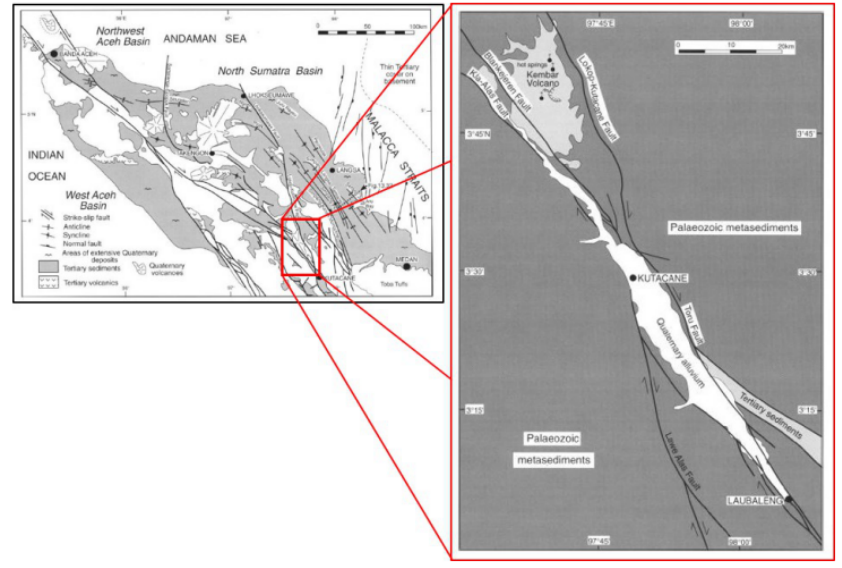

FIG. 9: Tectonic map of Aceh Province and Kutacane Regency, Aceh [3].

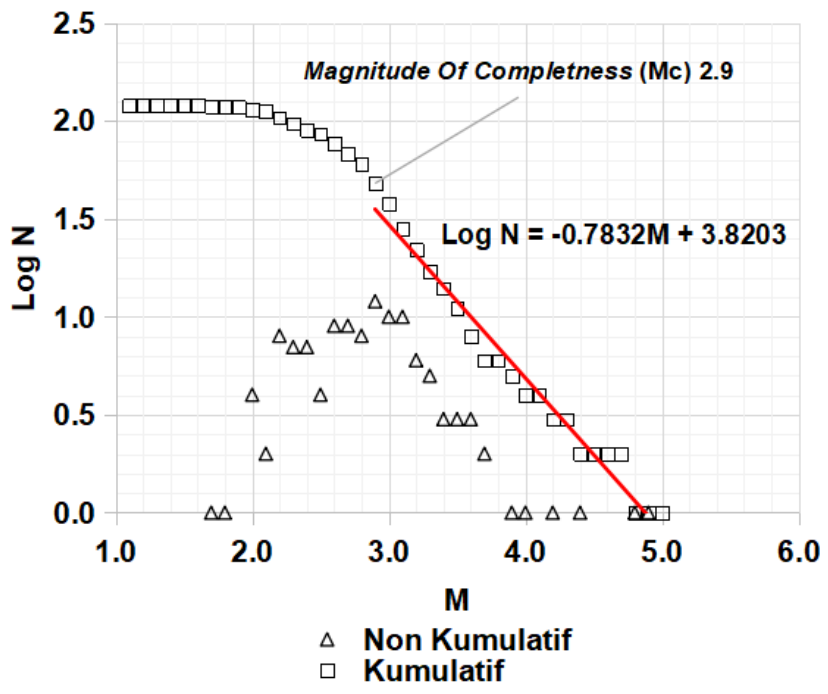

FIG. 10: Graph of Frequency Distribution-Magnitude (FMD) (Source: Data Processing, 2020).

stress. Thus, when that area already received some amount of stress, it will eventually break and produce an earthquake with a small magnitude. This type of area also known as creeping area that is indicated by high frequency of small earthquakes.

The PDF and CDF analyses support the b-value result. The PDF and CDF indicate that the Lokop-Kutacane fault has the highest probability of earthquakes to occur with magnitude of 3 to 4 . However, fault length analysis using WellsCoppersmith shows that maximum magnitude that possible in Lokop-Kutacane fault is as large as M7.6. This calculation is quite different with the historical data that only record the largest earthquake that occurred has only M6.8. Therefore, this research supports an effort to reduce disaster risk caused by earthquake that potentially produced by Lokop-Kutacane fault. 


\section{CONCLUSION}

The earthquake series in Gayo Lues is associated with Lokop-Kutacane fault and located in Mount Kembar territory with b-value of 0.7823 that is characterized by: (a) an area that has ductile rocks, (b) a region that has low stress concentration, (c) having high frequency of low magnitude earthquakes. Based on PDF and CDF, the highest probability of earthquake events in Lokop-Kutacane fault is between $3 \leq \mathrm{M}$ $\leq 4$ which is calculated at $28,9 \%$. Fault length analysis using Wells-Coppersmith equation shows that maximum magnitude of earthquake that is Lokop-Kutacane fault capable to produce is M7.6. The analysis result is higher than maximum earthquake recorded in catalog which is M6.8. The results support an idea that there should be disaster risk reduction effort caused by earthquake produced by Lokop-Kutacane fault in Gayo Lues.

\section{Acknowledgments}

We would like to say thank you to Badan Meteorologi Klimatologi dan Geofisika (BMKG), Observation team of Stasiun Geofisika Aceh Besar and Djati Cipto Kuncoro, S.Si as Head of Stasiun Geofisika Aceh Besar for the support and data availability of earthquake events in Gayo Lues.
[1] V.H. Banyunegoro, Z. Abidin, A. Jihad, Eridawati, and U. Muksin, "Probabilistic Seismic Hazard Analysis for Aceh Region Probabilistic Seismic Hazard Analysis for Aceh Region", IOP Conf. Ser. Earth Environ. Sci., vol. 273, 2019.

[2] M. Muzli et al., "The 2016 Mw 6.5 Pidie Jaya, Aceh, North Sumatra, earthquake: Reactivation of an unidentified sinistral fault in a region of distributed deformation", Seismol. Res. Lett., 2018.

[3] M.J. Crow, and A.J. Barber, "Structural map of Sumatra", no. 1990, pp. 01, 2003.

[4] K. Sieh, and D. Natawidjaja, "Neotectonics of the Sumatran fault, Indonesia", J. Geophys. Res. Solid Earth, vol. 105, no. B12, pp. 28295-28326, 2000.

[5] Pusat Studi Gempa Nasional, "Peta Sumber dan Bahaya Gempa Indonesia Tahun 2017”, 1st ed. Bandung: Kementerian Pekerjaan Umum dan Perumahan Rakyat, 2017.

[6] U. Muksin, et al., "AcehSeis project provides insights into the detailed seismicity distribution and relation to fault structures in Central Aceh, Northern Sumatra", J. Asian Earth Sci., vol.
171, pp. 20-27, 2019.

[7] J.R. Curray, "Tectonics and history of the Andaman Sea region”, J. Asian Earth Sci., vol. 25, no. 1, pp. 187-232, 2005.

[8] D.L. Wells, and J. Coppersmith, Kevin, "New empical relationship between magnitude, rupture length, rupture width, rupture area, and surface displacement", Bull. Seismol. Soc. Am., vol. 84, no. 4, pp. 974-1002, 1994.

[9] B.C. Papazachos et al., "Global Relations Between Seismic Fault Parameters and Moment Magnitude of Earthquakes", Bull. Geol. Soc. Greece, vol. XXXVI, no. April, pp. 1482-1489, 2004.

[10] E. Lusiani, S. Anwar, and M. F. Nugraha, "Penentuan Tingkat Seismisitas Wilayah Propinsi Aceh Dengan Metode Gutenberg Richter (Nilai a Dan Nilai B)", J. Meteorol. dan Geofis., vol. 19, no. 2, p. 71, 2019.

[11] J. Wesseloo, "Evaluation of the spatial variation of b-value", J. South. African Inst. Min. Metall., vol. 114, no. 10, pp. 823-828, 2014. 